"Acá estamos" Radio para alumnos en contextos de encierro

Fabián Castillo

Question/Cuestión, Vol. 2, № 66, Agosto 2020

ISSN 1669-6581

https://perio.unlp.edu.ar/ojs/index.php/question/index

IICom-FPyCS-UNLP

\section{“ACÁ ESTAMOS” RADIO PARA ALUMNOS EN CONTEXTO DE ENCIERRO}

\section{"HERE WE ARE" RADIO FOR STUDENTS IN CONINEMENT CONTEXTS}

Fabián Castillo

En la actualidad: Profesor y Regente del C.E.N.S. № 452, Unidades

penitenciarias 28, 35 y 36 de Magdalena

fabianalbertocastillo@hotmail.com.ar

\section{Resumen}

Experiencia radial surgida en el marco de esta pandemia mundial, donde los detenidos de la provincia de Buenos Aires deben cumplir la cuarentena, estar aislados de sus familiares y también del contacto con los docentes que dentro de la cárcel los forman en diferentes niveles educativos.

Por ello, el equipo docente del Centro Educativo del Nivel Superior $N^{\circ} 452$, que funciona dentro de los penales de Magdalena, pensó de qué manera poder realizar la continuidad pedagógica sin ingresar a la cárcel, así nace "Acá 
estamos" el programa radial, para que los internos puedan seguir recibiendo su formación académica, y los docentes puedan continuar con esta maravillosa vocación.

La radio una vez más como puente que acerca almas y también saberes.

\section{Palabras clave}

Radio, Aprendizaje, Contexto de encierro

\section{Abstract}

Radio experience emerged in the framework of this global pandemic, where detainees in the province of Buenos Aires must comply with quarantine, be isolated from their families and also from contact with the teachers who train them in different educational levels in prison.

For this reason, the teaching team of the higher level educational center $\mathrm{N}^{\circ}$ 452, which operates within the Magdalena prisons, thought about how to carry out pedagogical continuity without entering the prison, this is how "Here we are" the radio program was born, so that the interns can continue receiving their academic training, and the teachers can continue with this wonderful vocation. Radio once again as a bridge that brings souls and knowledge together.

\section{Keywords}

Radio, Learning, Confinement Context 


\section{Introducción}

Nombre del programa: "Acá estamos" (radio para alumnos en Contextos de Encierro)

Día y hora: viernes de 16 a 17 hs.

FM Victoria 98.5Mhz - Magdalena. Pcia. Bs.As.

Conducción: Fabián Castillo, profesor especializado en contexto de encierro del Centro educativo $N^{\circ} 452$ que funciona en la Unidad 28, 35 y 36 de Magdalena Institución educativa: Centro Educativo de Nivel Superior N452.

Dirección: Ruta 11 Km 111, Complejo Penitenciario Magdalena. Pcia. Bs.As. Audio: Lic. Gabriela Miranda (Profe que habla de resiliencia) Audio: Tito Lezcano (Ex alumno y autor de la poesía "Maestros tumberos").

\section{ENLACE}

https://go.ivoox.com/rf/55780358 